\title{
Finger millet-based staple beverages consumed by the Gadaba ethnic community of Odisha, India: Preparation and nutritive characteristics
}

\author{
ARUP KUMAR MISHRA ${ }^{1, \boldsymbol{\nu}}$, RANJANA BAJPAI ${ }^{2}$, AMRITA SWAIN \\ ${ }^{1}$ Department of Applied Geography, Ravenshaw University. Cuttack, Odisha 753003, India. Tel.: +91-7205056095, `email: arupmishra09@gmail.com \\ ${ }^{2}$ Department of Applied Geography, Ravenshaw University. Cuttack, Odisha 753003, India \\ ${ }^{3}$ Department of Zoology, Ravenshaw University. Cuttack, Odisha 753003, India
}

Manuscript received: 7 March 2021. Revision accepted: 21 April 2021.

\begin{abstract}
Mishra AK, Bajpai R, Swain A. 2021. Finger millet-based staple beverages consumed by the Gadaba ethnic community of Odisha, India: Preparation and nutritive characteristics. Biodiversitas 22: 2737-2742. The indigenous food and beverages reflect the acquaintance of ethnic population to local environmental settings. Development of diet structure includes diversities in food and beverages depend on the ethnic knowledge they perceive from their ancestors as well as from the environmental determinants. The Gadaba ethnic community being native to the southern part of Odisha state in India, developed the art to sustain them through rain-fed agricultural crops like finger millet and upland rice. These traditional non-hybrid crops give different dimensions to their food and beverage structure. In this case, the study focussed on finger millet-based staple beverages consumed by Gadaba ethnic community of this region. The effort is given to discuss the complete indigenous preparation process and nutritional parameters concerning two indigenous indispensable fermented beverages named Landa and Pej. The nutritional analysis of these beverages proved it to be a promising diet structure for sustainability.
\end{abstract}

Keywords: Finger millet, Gadaba, indigenous beverage, Landa, nutritional parameter, $P e j$

\section{INTRODUCTION}

Indigenous food and beverages identify a tribe or region due to its relation to the cultural and ecological aspects of people of that region. This kind of food and beverages might act as historical evidence regarding the origin of population in a region or the cultural significance of the concerned population group (Yovani 2019). Indigenous food and beverage practices are location-centric and deeply associated with socio-religious and cultural norms of tribal groups. For a long period of time, this traditional food and beverages proved to be helpful for human beings towards maintaining healthy and comprehensive life which is away from contemporary diseases (Pushpangadan et al. 2012). Ethnic acquaintances to fermented products are hereditary and diversified over territory due to geographical availability of raw materials. In Odisha, these products are mostly derived from crops like millets and rice. Traditional fermented products have minimal production cost, labor cost and relying on locally obtainable raw materials. These fermented foods and beverages form a part of sociocultural and ecological life of indigenous folks (Thakur et al. 2004). The Gadaba of Odisha is a vibrant tribe considered as earliest cultivator of this region (Padhi 2020). Their food and beverage forms imitate their traditional knowledge of agriculture and association with local environment. The cultivation products majorly deal with rice, finger millet, foxtail millet and little millet which reflect the food and beverage habits. In this study, the focus is given to understand the complete preparation process and nutritive value assessment of two frequently consumed fermented finger millet (Eleusine coracana $\mathrm{L}$ ) beverages namely Landa and $P e j$ which is considered a staple among the Gadaba tribe. The word millet came from the French term 'mille' represents one thousand or handful of thousand grains (Shahidi and Chandrasekara 2013; Ramashia et al. 2019). It belongs to the family Poaceae and locally called Mandia or Samel. Compare to other crops like paddy, barley or oats, finger millet named 'Super cereal' due to its rich nutrient composition and particularly high calcium content (Prajapati et al. 2019). Finger millet is a valuable crop for its resistance against pests, drought lenience, short growing season and its adaptability to varied range of environmental situation and thus emerged as an essential crop for future use (Chandra et al. 2016). The significance of finger millet is also lain in its slow digestibility and hence delivers energy for long hour of time (Gupta et al. 2017). Mineral content like potassium, sodium, calcium, magnesium, zinc, manganese and iron in finger millet shows the potentiality to eradicate type- 2 diabetes (Kumar et al. 2016). The millet grains which contain various phenolic compounds reported exhibiting antioxidant activities. These phenolic components have the capability to defend other dietary anti-oxidants from dilapidation at the intestine (Chandrasekara and Shahidi 2012). Presence of polyphenols led to reducing rate of fat concentration and slow release of sugars (low glycaemic index) and hence reduces the risk of heart problems, diabetes and high blood pressure (Kumar et al. 2018). 
The finger millet in this zone is predominantly cultivated with traditional process on local traces like san mandia, bad mandia, chilli mandia, dussera mandia, and telenga mandia (Pradhan et al. 2019). Landa is consumed particularly during evening hour for refreshment and includes a process of germination and popping. The germination and popping process increases the availability of nutrients like protein and carbohydrates and proved it to be a nutritious food (Chauhan and Sarita 2018). Germinated and fermented millet beverages develop the amount of soluble iron content and increase the dietary iron availability, thus combat the disease like anemia (Tatala et al. 2007). The short or long period consumption of beverages or porridges enhances the plasma total antioxidant capacity and also inhibits the antioxidant ability of patients with diabetes and metabolic syndrome (Kumari et al. 2020). Due to rich nutrient intakes through fermented porridges, it shows the quality to control diarrhoeal infections and considered as a remedy to malnutrition (Isingoma et al. 2015). For example, in a study over nutrition status of school children in Karnataka state of India, the fermented millet-based foods proved to improve the status of stunting and body mass index among the students (Anitha et al. 2019). Many households prepared Landa for own consumption as well as for selling purpose within community. $P e j$ is prepared from finger millet flour and is taken during lunch and dinner along with other items like rice and curry. It is a usual beverage compulsorily remained a part in lunch and dinner.

\section{MATERIALS AND METHODS}

\section{The study area}

The research was conducted in Tukum and Guneipoda village of Jalahanjar and Guneipoda gram panchayat respectively (Figure 1). Tukum is situated at 18.628641 north latitude and 82.548123 east longitudes. Guneipoda is situated at 18.573981 north latitude and 82.529118 east longitudes. These two sites are located in Lamtaput block under Koraput district of Odisha state in India.

\section{Methods}

Participant observation method applied to understand the complete preparation of Landa and Pej. The samples of each beverage were collected from concerned area and tested at the 'Biochemistry and Molecular Biology Laboratory' of the Department of Zoology, Ravenshaw University for analysis of nutritional parameters.The parameters included $\mathrm{pH}$, fat, protein, carbohydrate content, energy, forms of amino acid, yeast and the functional bacterium. The $\mathrm{pH}$ of beverages was recorded through a standard $\mathrm{pH}$ meter and using $\mathrm{pH}$ paper.

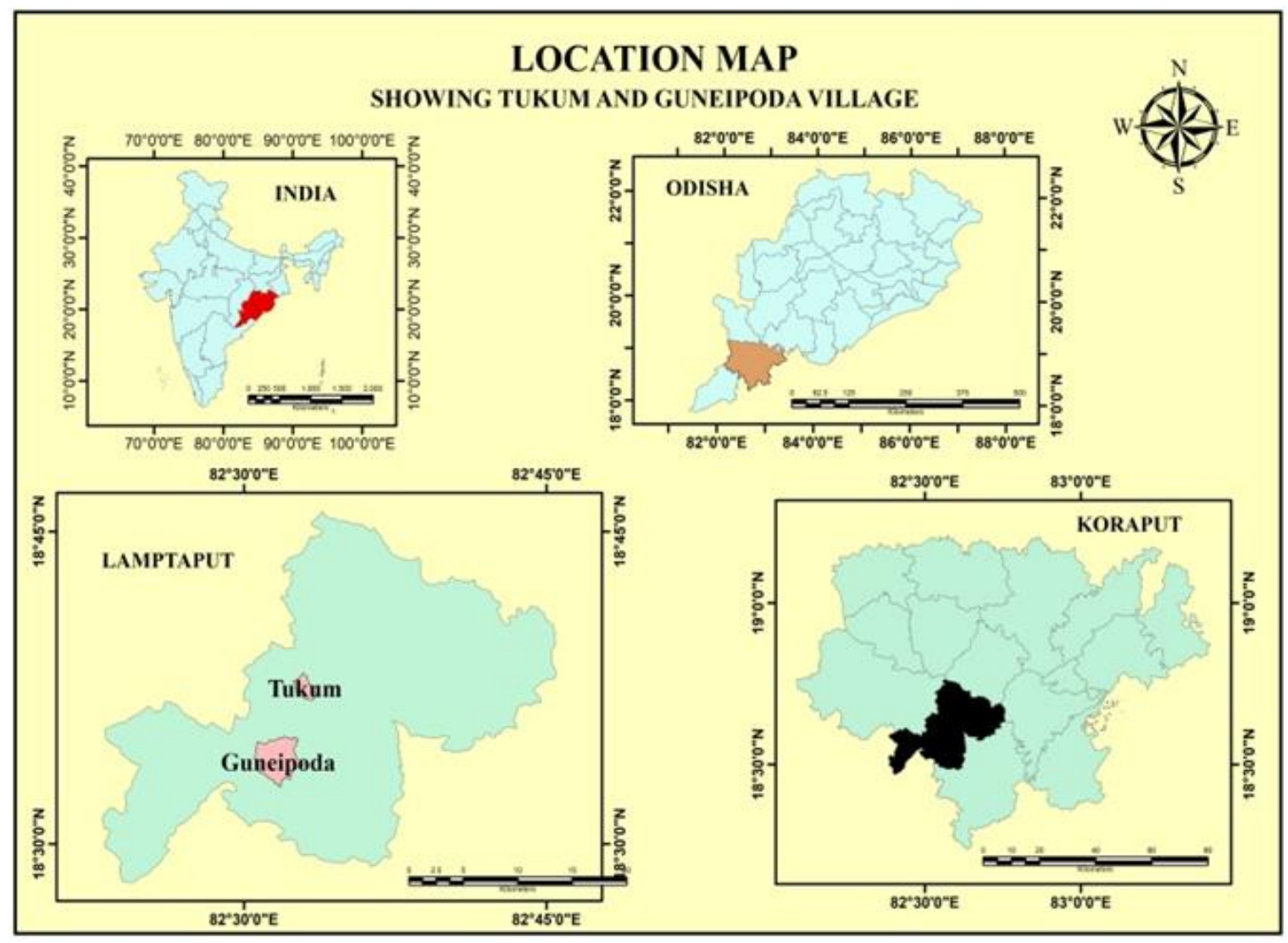

Figure 1. The study area in Odisha, India 


\section{Estimation of total protein by Lowry method}

Lowry method was applied using Folin phenol reagent to detect the presence of protein in the sample (Lowry 1951) and the absorbance measured by using spectrophotometer.

Reagents: Solution A: Alkaline sodium carbonate solution $2 \%(\mathrm{w} / \mathrm{v})$ in sodium hydroxide $(0.1 \mathrm{~N})$ (i). Solution B: Copper sulphate $(\mathrm{CuSo} 4) 0.5 \%(\mathrm{w} / \mathrm{v})$ in distilled $\mathrm{H}_{2} \mathrm{O}$ (ii). Solution C: Potassium sodium tartrate solution $1 \%$ (w/v) in distilled $\mathrm{H}_{2} \mathrm{O}$ (iii). Biuret reagent - Mixture of solution $\mathrm{A}$, solution $\mathrm{B}$ and solution $\mathrm{C}$ in ratio 100: 2: 2 respectively, and prepared just prior to the acid (iv). Folin reagent - Commercially available solution of sodium tungstate and sodium molybdate in Phosphoric acid Hydrochloric acid (v). Folin-Cocteau - Folin-Cocteau reagent is diluted in distilled water (1:2) V/V and freshly prepared prior to acid (vi). Standard protein - Bovine Serum Albumin $(1 \mathrm{mg} / \mathrm{mL})$ in distilled $\mathrm{H}_{2} \mathrm{O}$ (vii).

Procedure: $0.1,0.2,0.3,0.4,0.5 \mathrm{~mL}$ of standard protein solution was taken in test tubes in duplicates having Bovine Serum Albumin concentration ranging from 20 to $100 \mathrm{ug}$. The volume of each test tube was made up to 0.5 $\mathrm{mL}$ by distilled water. In a test tube, a blank sample was prepared by taking $0.5 \mathrm{~mL}$ of distilled water without protein sample. To all the test tubes $5 \mathrm{~mL}$ of Biuret reagent was added. Then the solutions in the test tubes are mixed thoroughly by a cyclometer. Then the solutions in test tubes are incubated for 10 minutes. To all the test tubes $0.5 \mathrm{~mL}$ of Folin reagent was added. Then the solutions in test tubes are incubated for 30 minutes. The spectrophotometer was put on and allowed to stabilize for at least 20-30 minutes. Then the absorbance of each solution was taken at 700nm (x). A graph was plotted by taking concentration of protein on $\mathrm{x}$-axis and their respective absorbance on $\mathrm{y}$-axis.

\section{Qualitative test for amino acids:}

Five qualitative tests were conducted for amino acid concentrations. Following are the tests with result: (i) Ninhydrin test: positive result with purple colors in both solutions. (ii) Millon's test: positive result with reddishbrown colors in both solutions. (iii) Xanthoproteic test: positive result. Initially yellow precipitate, then orange colors in both solutions. (iv) Sakaguchi test: positive result with reddish colors in both solutions. (v) Sulfide test: positive result for both the solutions.

\section{Estimation of total carbohydrate by Anthrone reagent:}

Spectrophotometer is used to measure the absorbance of carbohydrates through Anthrone test using Dreywood's Anthrone reagent (Morris 1948). Carbohydrates are first hydrolyzed into simple sugar using $\mathrm{H}_{2} \mathrm{SO}_{4}$ in hot acidic medium. Glucose is dehydrated in hydroxymethylfurfural. This compound reacts with anthrone to give blue-green colored product with an absorption maximum at $620 \mathrm{~nm}$.
Reagents: Glucose stock solution: It was prepared by dissolving 10mg of glucose in $100 \mathrm{~mL}$ of distilled water (i). Anthrone reagent: It was prepared by dissolving $0.2 \mathrm{~g}$ of anthrone in $100 \mathrm{~mL}$ of concentrated $\mathrm{H}_{2} \mathrm{SO}_{4}$ (ii).

Procedure: The solution of known glucose concentration of $0.1 \mathrm{mg} / \mathrm{mL}$ was prepared in a series of testtube in duplicates of known glucose concentration ranging from 20 to $100 \mathrm{ug}$. Then distilled water was added to each test tube followed by $4 \mathrm{~mL}$ of Anthrone reagent such that the total volume in test tubes was $5 \mathrm{~mL}$. Blank was prepared by taking $1 \mathrm{~mL}$ of distilled water and $4 \mathrm{~mL}$ of Anthrone reagent making the total volume $5 \mathrm{~mL}$. Then the solution in all the test tubes was mixed thoroughly by a cyclometer and was incubated for 10 minutes at $97^{\circ} \mathrm{C}$. After incubation, the solution were let to cool down. Then absorbance of each solution was taken using spectrophotometer at $620 \mathrm{~nm}$. A graph was plotted by taking concentration of glucose on $\mathrm{X}$-axis and their absorbance on Y-axis.

\section{Qualitative test for carbohydrate:}

Four qualitative tests were conducted to know the presence of carbohydrates in both solutions and to detect the presence of reducing sugars. Following are the test with result: (i) Molisch's test: positive result. (ii) Fehling's test: positive result. (iii) Benedict's test: positive result. (iv) Barfoed's test: positive result.

\section{Gram's staining method to identify functional bacterium:}

Stains and dyes are widely used in the scientific field to highlight the structure of the biological specimens, cells, tissues, etc. The most widely used gram staining procedure in microbiology is the gram stain, discovered by the Danish scientist and physician Hans Christian Joachim Gram in 1884. Gram staining is a differential staining technique that differentiates bacteria into two groups, i.e.: Gram positives and Gram-negatives.

Procedure: A single drop of distilled water was taken on the surface of the glass slide. A wire loop was sterilized and a colony was picked from the growth medium and mixed with the drop on the glass slide and formed a smear and dried over flame. After heat fixing the chemicals were applied to the smear slide. After that Crystal violet was applied for 1 minute to which is also called primary dye followed by flooding the mordant iodine for 1 minute and washed off by distilled water. The iodine was rinsed of after 1 minute by distiled water. After that decolorizer is applied for $30 \mathrm{sec}$ to 1 minute and rinsed from the slide with distilled water. After washing the decolorizer Safranin was applied for $45 \mathrm{sec}-1 \mathrm{~min}$ which is fixed in cell wall gramnegative bacteria. The Safranin was rinsed of from the smear and smear was allowed to dry. After drying the slide, it was covered with cover with coverslip and observed under microscope. 


\section{RESULTS AND DISCUSSION}

\section{Preparation of Landa}

Preparation of Landa followed a unique technique. It carries one raw material with two different forms. One is germinated finger millet (Figure 2.A) and another is finger millet flour. Firstly the finger millet soaked in water for germination which takes around twenty-four hours. After proper germination, it is left for dry and then bruised with the help of jata (a tool made from stone for pounding spices and cereals) (Figure 2.B). These bruised millets were cooked in a pot for around two hours. In between the cooking processes, the early prepared millet flour is added on top of the cooked bruised millet. Water is added as per requirement to soften the viscosity. After the preparation is over, it is left for cooling and natural fermentation at a corner of the house for 3 to 4 days. Popping of natural bubbles gives indication of strong fermentation and ready for drink. It is a non-toxic beverage with astringent taste consumed mostly during working hours at fields and in evening hour for refreshment. In most cases, it acts as a substitute of meals during lunch hour. Landa (Figure 2.C) is usually a part of evening gossip among the male fellows of community.

\section{Preparation of $P e j$}

$P e j$ refers to finger millet gruel. It is called Samel Pej in Gutob language by Gadaba people in particular and commonly calledas Mandia Pej in regional dialect of Koraput district in Odisha. It is a mushy semi- liquid substance made from a mixture of Samel (finger millet) i.e. Eleusine coracana L and Keram (rice) i.e. Oryza sativa L. Initially the finger millet collected from field is dried and finely ground into flour with the help of rumna (the traditional tool with two flat rounded stonework for grinding grains). The flour is mixed with water in a ratio of
1 glass flour: 2 glass water and kept for 1 to 2 nights. On the next day, a small quantity of half boiled rice with adequate water is added with the existing mixture of millet flour and water and boiled for around one hour to get the final Samel Pej. It can be kept for cooling a little longer time to get fermented which gives a sour taste. Pej (Figure 2.D) remain as a compulsory diet during lunch and dinner. It shows a cultural attachment of Gadabas with finger millet as it is produced as a parent crop. Inheritance of $P e j$ through generations remarkably preserved a traditional food with better nutritional characteristics. According to a young Gadaba man from Tukum village named Gobind Kirsani, 'we can skip rice during meal time but skipping Pej is very difficult'.

\section{Nutritional analysis of Landa and $P e j$}

The nutritional parameters concerning collected samples included $\mathrm{pH}$, fat, protein, carbohydrate, energy, forms of amino acid and the functional bacterium (Table 1). The $\mathrm{pH}$ of collected samples varied from 3.62 in Landato 4 in Pej. The protein content of Landa was found to be $1.026 \mathrm{mg} / \mathrm{mL}$ and it was found to be $0.228 \mathrm{mg} / \mathrm{mL}$ in Pej. Carbohydrate content of samples ranged from 3.6 $\mathrm{mg} / \mathrm{mL}$ in Landa to $3.424 \mathrm{mg} / \mathrm{mL}$ in Pej while the form of carbohydrate in both the beverages is reducing sugar (Hexose). Both the beverages represented the absence of fat. The energy value of Landa and Pej stood at 1.8504 $\mathrm{Cal} / 100 \mathrm{~mL}$ and $1.4608 \mathrm{Cal} / 100 \mathrm{~mL}$ respectively. Yeast was present in both the beverages and Coccus sp. was the functional bacterium responsible for fermentation process in Landa and Pej (Figure 3). The form of amino acids was similar in both the beverage and includes tyrosine (Y), phenylalanine $(\mathrm{F})$, tryptophan $(\mathrm{W})$, arginine $(\mathrm{R})$ and cysteine (C).
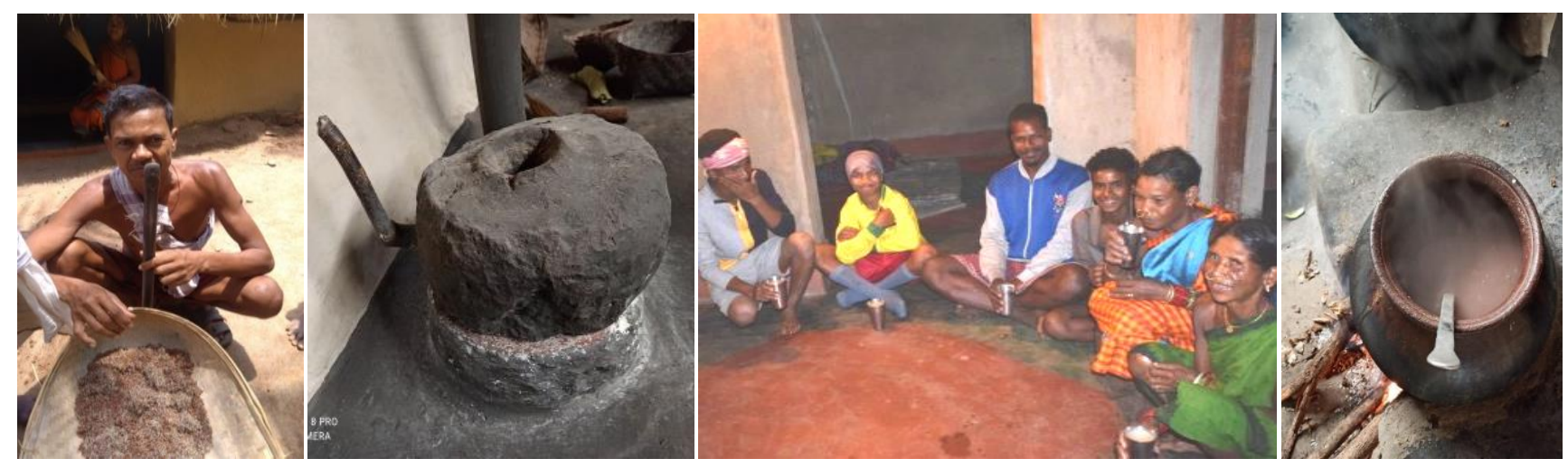

Figure 2. A. Germinated finger millet, B. Traditional tool (Jata), C. Women and children enjoying Landa during evening hour, D. Pej at its final form 

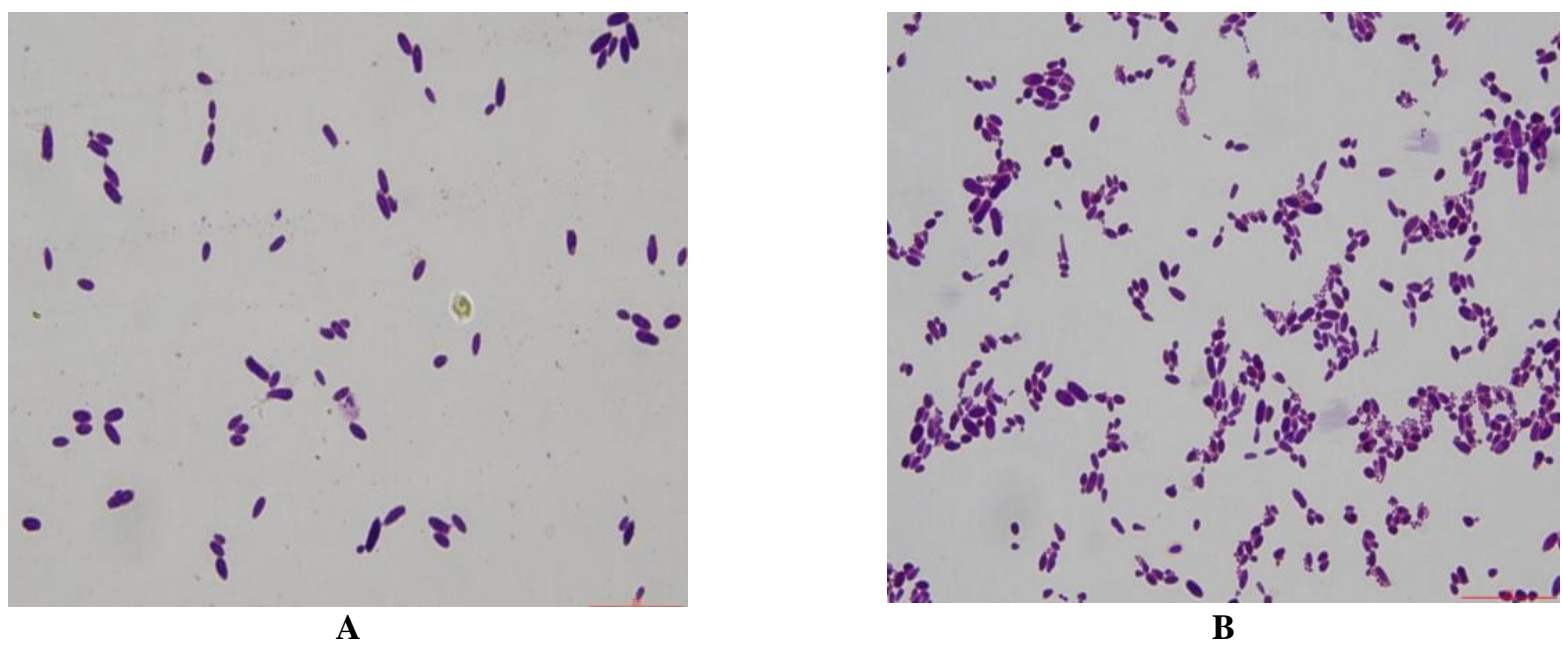

Figure 3. Gram's staining photograph of: A. Landa, B. Pej

Table 1. Nutritional value of Landa and $P e j$

\begin{tabular}{lll}
\hline Nutritional value & Landa & Pej \\
\hline $\mathrm{pH}$ & 3.62 & 4 \\
Protein & $1.026 \mathrm{mg} / \mathrm{mL}$ & $0.228 \mathrm{mg} / \mathrm{mL}$ \\
Fat & Absent & Absent \\
Carbohydrate & $3.6 \mathrm{mg} / \mathrm{mL}$ & $3.424 \mathrm{mg} / \mathrm{mL}$ \\
Form of carbohydrate & Reducing sugar & Reducing sugar \\
& (Hexose) & (Hexose) \\
Energy value: $\mathrm{kcal} / 100 \mathrm{~mL}$ & $1.8504 \mathrm{Cal} / 100 \mathrm{~mL}$ & $1.4608 \mathrm{Cal} / 100 \mathrm{~mL}$ \\
& $2.0557 \mathrm{Cal} / 100 \mathrm{gm}$ & $1.5046 \mathrm{Cal} / 100 \mathrm{gm}$ \\
Form of amino acid & Tyrosine $(\mathrm{Y})$, Phenylalanine $(\mathrm{F})$, Tryptophan $(\mathrm{W})$, & Tyrosine $(\mathrm{Y})$, Phenylalanine $(\mathrm{F})$, \\
& Arginine $(\mathrm{R})$, Cysteine $(\mathrm{C})$ & Tryptophan $(\mathrm{W})$, Arginine $(\mathrm{R})$, Cysteine $(\mathrm{C})$ \\
Yeast & Present & Present \\
Functional bacterium & Coccus sp. & Coccus sp. \\
\hline
\end{tabular}

To conclude, the study exhibits two indigenous staple beverages of Gadaba tribe in which it was found the availability of good sources of one or more nutrients. This may be the first report on dietary and nutrient aspects related to finger millet-based beverages practiced by ethnic group of Odisha. The absence of fat, reducing sugar, amino acid availability and presence of yeast represents these beverages as dynamic and solution to many contemporary diseases. The forms of amino acid signified the beverages in terms of their qualitative importance. These indigenous beverages in natural means are no doubt can maintain promising holistic health status. Looking at the nutrient parameters, a further reorientation through scientific procedure can help these indigenous nutrient-rich drinks to act as substitute for many marketed packaged beverages.

\section{ACKNOWLEDGEMENTS}

The authors are thankful to respondents under study. Prof. Luna Samanta, department of Zoology, Ravenshaw University is highly acknowledged for providing laboratory assistance to complete this piece of work. Research does not receive any specific grants from funding agencies. All authors have no competing interest to declare.

\section{REFERENCES}

Anitha S, Potaka-Kane J, Tsusaka TW, Tripathi D, Upadhyay S, Kavishwar A, Sharma N, Neduraman S. 2019. Acceptance and impact of millet-based mid-day meal on the nutritional status of adolescent school-going children in a peri-urban region of Karnataka state in India. Nutrients 11 (9), 2077. DOI: 10.3390/nu11092077

Chandra D, Chandra S, Pallavi, Sharma AK. 2016. Review of finger millet (Eleusine coracana (L.) Gaertn): A powerhouse of health benefiting nutrients. Food Sci Hum Well 5: 149-155. DOI: 10.1016/j.fshw.2016.05.004.

Chandrasekara A, Shahidi F. 2012. Bioaccessibility and antioxidant potential of millet grain phenolics as affected by simulated in vitro digestion and microbial fermentation. J Func Foods 4: 226-237. DOI: 10.1016/j.jff.2011.11.001

Chauhan ES, Sarita. 2018. Effects of processing (Germination and Popping) on the nutritional and anti-nutritional properties of finger millet (Eleusine corocana). Cur Res Nut food Sci 6 (2): 566-572. DOI: 10.12944/CRNFSJ.6.2.30.

Gupta SM, Arora S, Mirza N, Pande A, Lata C, Puranik S, Kumar J, Kumar A. 2017. Finger millet: A "certain" crop for an "uncertain" future and a solution to food insecurity and hidden hunger under stressful environments. Front Plan Sci 8: 643. DOI: 10.3389/fpls.2017.00643. 
Isingoma BE, Samuel M, Edward K, Maina G. 2015. Improving the nutritional value of traditional finger millet porridges for children aged 7-24 months in Bujenje county of Western Uganda. Afr J Food Sci 9 (8): 426-436. DOI: 10.5897/AJFS2015.1285.

Kumar A, Metwal M, Kaur S, Gupta AK, Puranik S, Singh S, Singh M, Gupta S, Babu BK, Sood S and Yadav R. 2016. Nutraceutical value of finger millet [Eleusine coracana (L) Gaertn.], and their improvement using omics approaches. Front Plant Sci 7: 934. DOI: 10.3389/fpls.2016.00934.

Kumar A, Tomer V, Kaur A, Kumar V, Gupta K. 2018. Millets: a solution to agrarian and nutritional challenges. Agric Food Secur 7 (1): 1-15. DOI: 10.1186/s40066-018-0183-3.

Kumari D, Chandrasekara A, Athukorale P, Shahidi F. 2020. Finger millet porridges subjected to different processing conditions showed low glycemic index and variable efficacy on plasma antioxidants capacity of healthy adults. Food Prod Proc Nutri 2 (1): 1-11. DOI: 10.1186/s43014-020-00027-9.

Lowry OH, Rosebrough NJ, Farr AL, Randall RJ. 1951. Protein measurement with Folin phenol reagent. J Biol Chem 193: 265-275. PMID: 14907713.

Morris DL. 1948. Quantitative determination of carbohydrates with Dreywood's anthrone reagent. Science 107: 254-255. DOI: 10.1126/science.107.2775.254.

Padhi SR. 2020. An ethnographic manifestation of religious life of Gadaba tribe in its changing dimensions. J Rel Heal 1-8. DOI 10.1007/s10943-020-01028-1.
Pradhan A, Panda AK, Bhavani RV. 2019. Finger millet in tribal farming systems contributes to increased availability of nutritious food at household level: Insights from India. Agric Res 8 (4): 540-547. DOI: 10.1007/s40003-018-0395-6.

Prajapati MR, Dave PH, Sable PA. 2019. Nutritional and functional benefits of finger millet (Eleusine coracana). Int J Pure App Biosci 7 (1): 342-345. DOI: 10.18782/2320-7051.7318

Pushpangadan P, Dan VM, Ijinu TP, George V. 2012. Food, nutrition and beverage. Ind J Trad Know 11 (1): 26-34.

Ramashia SE, Anyasi TA, Gwata ET, Meddows-Tylor S, Jideani AIO. 2019. Processing, nutritional composition and health benefits of finger millet in sub-Saharan Africa. Food Sci Technol 39 (2): 253266. DOI: $10.1590 /$ fst. 25017.

Shahidi F, Chandrasekara A. 2013. Millet grain phenolics and their role in diseases risk reduction and health promotion- review. J Func Food 5 (2): 570-581. DOI: 10.1016/j.jff.2013.02.004.

Tatala S, Ndossi G, Ash D, Mamiro P. 2007. Effect of germination of finger millet on the nutritional value of foods and effect of food supplement on nutrition and anemia status in Tanzanian children. Tanzan Heal Res Bull 9 (2): 77-86. DOI: 10.4314/thrb.v9i2.14308.

Thakur N, Savitri, Bhalla TC. 2004. Characterization of some traditional fermented foods and beverages of Himachal Pradesh. Ind J Trad Know 3 (3): 325-335

Yovani T. 2019. Lamang Tapai: The ancient Malay food in Minangkabau tradition. J Ethn Foods 6 (1): 1-9. DOI: 10.1186/s42779-019-0029-z . 